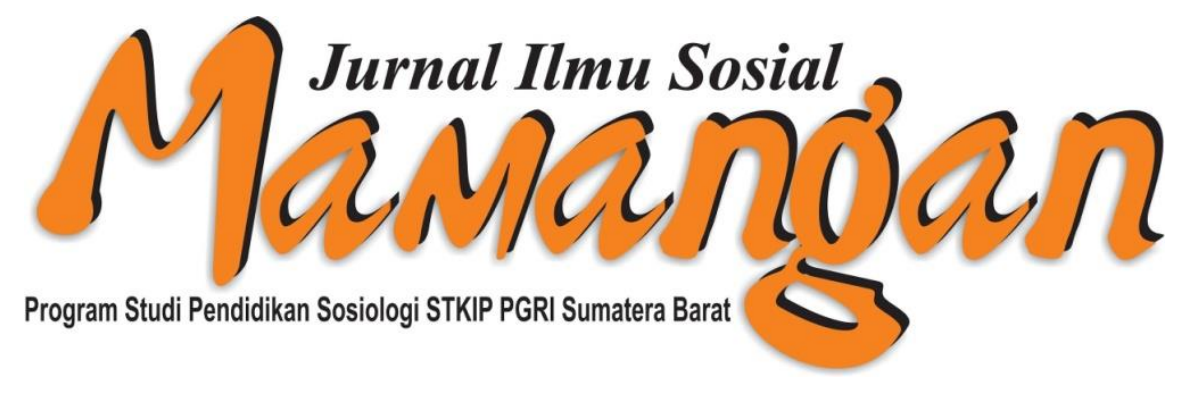

Jurnal Ilmu Sosial Mamangan

Volume 8, Issue 2, July-December, 2019

Development of Tourism Based on Empowerment of Community in Mandeh Tourism Area of South Coast West Sumatra

Author (s) : Sarbaitinil

Source $\quad$ : JurnaI lmu Sosial Mamangan, Volume 8, Issue 2, July-December, 2019

Publisher : : Laboratorium Pendidikan Sosiologi, STKIP PGRI Sumatera Barat

To Cite This Article:

Sarbaitinil. 2019. Development of Tourism Based on Empowerment of Community in Mandeh Tourism Area of South Coast West Sumatra. Jurnal Imu Sosial Mamangan, Volume 8, Issue 2, July-December. 2019: 60-70.

Copyright (C) 2019, Jurnal Ilmu Sosial Mamangan

ISSN: 2301-8496 (Print) \& 2503-1570 (Online)

Laboratorium Pendidikan Sosiologi STKIP PGRI Sumatera Barat 


\title{
DEVELOPMENT OF TOURISM BASED ON EMPOWERMENT OF COMMUNITY IN MANDEH TOURISM AREA OF SOUTH COAST WEST SUMATRA
}

\author{
Sarbaitinil \\ Sekolah Tinggi Keguruan dan Ilmu Pendidikan (STKIP) PGRI Sumatera Barat \\ Email: bet_sarbaitinil@yahoo.co.id
}

\begin{abstract}
The aim of this study is to formulate a model for developing marine tourism by empowering the potentials of the Mandeh tourism area community. This is because the community involvement in tourism development is still low and still at the level of independent participation. With a community-based approach the community's sense of belonging is expected. This study uses a qualitative descriptive approach to get detail picture of the experiences of individuals in the development of community-based marine tourism. The determination of informants was obtained by purposive sampling techniques, such as the government and tourism stakeholders, tourists and the coastal communities of the Mandeh tourism area. In order to obtain valid data basedon reality, data triangulation is used, while data analysis techniques used is interactive analysis. The results of this study indicate that the Mandeh region has potential resources that can be developed by empowering the community as implementing actors. The recommended alternative model for developing marine tourism uses the empowerment of community approach and emphasizes full involvement of the community in the process of developing marine tourism, such as diving, swimming, crossing the islands using speedboad transport services, and inviting tourists to see coral reef in the sea.
\end{abstract}

Keywords: Marine Tourism, Government, interest, community, tourists

\section{INTRODUCTION}

Indonesia is the second largest country in Asia and the seventh in the world, and also the largest archipelagic country in the world which has land area of $1 / 3$ of the sea area and $2 / 3$ of the ocean from the total area. As an archipelago, Indonesia has thousands of islands with wide seas, so it is possible to have a lot of natural tourism potential and diverse. One type of tourism that Indonesia has is marine tourism. The development of the tourism sector such as marine tourism can directly increase the income of the community, especially the local community in each tourist destination. Socially and politically, the development of marine tourism for the archipelago's tourism trips can foster and strengthen the love of the motherland and national unity. On a regional basis, Indonesian tourism has a multisectoral character and across regions will connect the development of tourism infrastructure. Moreover, facilities and the creative economy will drive the flow of investment and regional development (RPJMN Tourism Sector 2015 - 2019. 2014: iv) 
Related to the development of the tourism sector, Pages (2009) discusses 5 (five) issues regarding tourism development, namely: (1) Boostern Approach. This is a simple approach which explains that the tourism gives good effect to the place and community around it. However, the existence of community involvement in the planning process and the carrying capacity of the region has not been fully approved. (2) The economic industry approach. The tourism development approach emphasize the economic goals more than social and environmental goals. Beside that increasing the experience and satisfaction of visitors is the main goal. (3) Physical spatial approach. Related to the development of this tour, it discusses land use with a development strategy based on spatial principles. For example the division of visitors to avoid conflicts between visitors. (4) Community approach. Tourism development planning emphasizes community involvement in the process of tourism development. (5) Sustainable approach. Tourism development by considering aspects of sustainability or future interests in resources and economic development of the environment.

The tourism development approach emphasizes maximum community involvement in the process of tourism development such as the development of marine tourism areas which must be linked to a variety of fundamental interests, namely empowering coastal communities. Coastal communities are people who have a lot of knowledge about the objective conditions of their area. Therefore in developing marine tourism areas, an approach to the local community should always begin as a model of participatory planning approaches. It can place coastal communities to enable sharing, improve and analyze their knowledge about the nautical and coastal life, making plans and acting.

Community-centered development places more emphasis on empowerment, which sees the potential of the community as the main resource in development and views togetherness as a goal to be achieved in the development process. As stated by (Kevin Mearns. 2010: Andrea Yanes. 2019) that Community-based tourism is "the concept of developing a tourist destination through the empowerment of local communities, where the community contributes to the planning, management and voting in the form of decisions in its development". Furthermore, based on the results of research by Cevat Tosun (2004) in the development of community-based tourism, around 53\% of respondents stated that tourism development policies must be consulted with the local community. In addition, the majority of respondents (94.7\%) rejected the statement that "local people must not participate in the development of tourism in any way".

Therefore local community empowerment is something that must be done in the development of tourism. Because the community is one of the actors involved and has a role in driving the tourism system. These actors, both individuals and groups, are also referred to various sectors related to tourism. As the people who related to tourism as stated by Pitana \& Gayatri (2005) that in general, the the people who related to tourism are grouped in three main pillars, namely: (1) the community, (2) the private sector, and (3) the government. The pillar of society refers to the general public at a tourist destination or location, the legal owner of various resources which constitute tourism capital such as culture. This includes community leaders, intellectuals, nongovernmental organizations, and mass media. The next pillar is the private pillar, namely the tourism business association and entrepreneurs who are directly or indirectly related to tourism. The final pillar is the government that has authority in various administrative areas, ranging from the central government, states, provinces, districts, and so on.

Based on some of the concepts put forward by Pitana \& Gayatri above, it can be said that tourism development should involve the government, the community and the private sector. Tourism development does not only rely on the business capability of the private sector. Without the support of the government and the community, the development of tourism businesses oby the private sector cannot run smoothly. Neither does the development of tourism which is 
only managed by the government without involving other pillars. The government will experience difficulties in increasing investment and capital in the development of tourism. However, the most important thing is the involvement of community pillars which have been often ignored in tourism development. As a result, people, especially those who live in the region or tourist destinations do not feel the benefits of the tourism development around them. Even if they are involved, the role is very minimal so that it does not have a significant impact on the welfare of the local community. This is in accordance with the statement of Anuar \& Sood (2017). The local communities around tourist destinations are only spectators while at the same time they are affected by various negative social, economic and environmental impacts resulting from the development of tourism in their area.

Furthermore Yulius, et al (2018) stated that in the development of marine tourism there are some basic concepts that must be understood, namely:

1. The principle of co-ownership is that the marine tourism area is shared property, the community rights in it must be recognized, but the protection must be done together as well.

2. The principle of co-operation / co management is that joint ownership requires the coastal management which can be carried out together with all community components (stakeholders) consisting of government, community and non-governmental organizations (NGOs).

3. The principle of co-responsibility is that the existence of a marine tourism area is a shared responsibility, because the management of a marine tourism area is a shared goal.

These three principles are implemented in an integrated manner, so that the function of coastal sustainability is achieved by actively involving the participation of communities around the coast. Therefore, the community who will participate needs economic, social and educational empowerment. For this reason, the role of government is needed in empowering communities around the coast to improve their welfare through 6 principles of empowerment, namely: (Sastrayuda, G.S, 2010)

1. Community capital (social capital) is cooperation and agreed values.

2. Infrastructure and development of informal social institutions which oriented towards progress.

3. The ownership orientation (development orientation) is development which is based on exploring the ability of the community as a development model.

4. Collaboration, to develop patterns of cooperation that grow from within.

5. Vision and strategic actions, namely building a vision, mission and action.

6. The art of democracy, namely developing roles and participations that grow from within.

The definition of marine tourism according to the Tourism Act No.10 of 2009 is a type of alternative tourism related to marine that is managed commercially in sea waters, beaches, lakes, rivers and reservoirs, both above sea level and activities carried out below sea level. Basically, marine tourism is a lot of tourism that is associated with water sports, especially in lakes, Bengawanas, beaches, bays or offshore such as fishing, sailing, photographing under the sea, surfing competitions, rowing races, going around looking around marine park with a beautiful view below the surface of the water, as well as a variety of water recreation that is mostly done in maritime areas or countries. In developing marine tourism, the concepts needed for the development of the region are:

1. The uniqueness of nature

2. Ecosystem characteristics

3. The specificity of art and culture

4. Community characteristics

The approach to the development of marine tourism areas is more directed and used towards efforts to develop environmentally friendly tourism areas. The development of marine tourism areas must avoid environmental pollution, destruction and waste of marine natural resources. The marine tourism development of the area has a close relationship with the role of the Coastal community. Therefore, it is necessary 
to determine the appropriate zonation of each region, so that there is no conflict of interests between residential growth zones and marine tourism zones. It must be managed and utilized for infrastructure development activities that can encourage growth between regions through priority development systems. Marine tourism area based on the type of potential and natural character possessed by each region.

One of the marine tourism areas that can be developed based on the type of potential and natural character possessed by each region is the Mandeh tourism area. The tourist area is located in the South Coastal district of West Sumatra province, precisely in the Koto XI Tarusan subdistrict, it can be reached about $56 \mathrm{~km}$ from the city of Padang. Mandeh is a tourist area that was previously included in the National Tourism Development Master in 2004, because of its beauty. Thus it makes the Mandeh region's name popular or known at the national and even international level. The Mandeh region also has a beautiful coral reef that is no less good than other places. In fact, the Regional Government of South Pesisir Regency in 2007 has compiled a master plan for the development of the Mandeh tourism area, it is 70.32 hectares (ha) of coral reefs, 313.32 ha of mangroves, 21.23 ha of seagrass beds and diversity of area of 404.55 ha. Until now there are about 70 hectares of coral reefs that are still maintained (Tourism Agency, 2018).

In addition there is the beauty of a 400 hectare mangrove forest and various diverse marine life. This area is one of the marine tourism areas that has many beautiful islands and can be visited by using a speed boat which is rented by the local community. This beauty is a natural potential with a beautiful panoramic view of the islands and stretches around the Mandeh region. The fact that the Mandeh tourist area is the combination of unspoiled hills with islands that march from North to South tourist area, so that the Mandeh region is called as "The Paradise of south", as revealed by the Minister Tourism, Arif Yahya (in https: // republika. co.id/ berita/ nog $22 \mathrm{u} /$ menpar-t Preview-kawasanwisata-mandeh-di-sumbar).

The development of the Mandeh beach marine tourism in South Pesisir refers to the
Vision "The realization of an Independent, Superior, Religious and Prosperous South Pesisir Regency Community". Next through the mission "Increasing the Attractiveness of Marketing, Industry, Institutional and Tourism". With the direction of tourism development policy based on Adat Basandi Syarak, Syarak Basandi Kitabullah. However, the implementation in the development of tourism is still not optimal, especially related to the development of marine tourism which still does not empower the potentials that are owned by the community along the coast of the Mandeh tourism area. In fact coastal communities have the potential that can be utilized by the government in the development of tourism, but that potential has not been utilized properly. One of the potentials of the coastal community is expertise in diving, swimming, and canoeing and riding speed boat, all of which can be used as livelihoods to improve the economy of coastal communities.

Referring to some of the problems above, the aim of this research is to formulate a model for developing marine tourism that empowers the potentials of the coastal communities of the Mandeh tourism area. This is because the community involvement in tourism development is still low and is still at the level of independent participation. With a community-based approach and community empowerment, it is expected that the emergence of a sense of belonging of the community in the tourism sector in the South Coastal District will ultimately stimulate community participation in the development of the tourism sector, especially marine tourism.

\section{RESEARCH METHODS}

This study uses a qualitative descriptive approach to get detail picture of the experiences of individuals in the development of community-based tourism. This is in line with the opinion of Rubin and Babbie (2008): "Qualitative research methods attempt to tap deeper the meanings of particular human experiences and are intended to generate qualitative data: theoritically richer observations that are not easily reduced to numbers". 
The types of data in this study consisted of primary data and secondary data. Primary data was obtained by conducting detail interviews and unstructured interviews, and carrying out Focus Gorup Discussion (FGD). Secondary data is in the form of documents related to tourism development policies and programs implemented by the Government. In this case the researchers get help from the Regional Government Work Unit (SKPD) which deals with tourism, the Tourism Office.

Interviews, observations, and documentation studies are the methods used by researcher to collect data. In the context of primary data collection, the researcher used interviews. Meanwhile, in the context of secondary data collection, researcher conducted direct observations and also conducted a documentation study for several days in the field. In this process, researcher also conducted unstructured interviews with residents around the tourist area.

Data processing is done after the data is collected. In the process of data processing, sorting and grouping data obtained directly in the field as well as secondary data. The results of the classification are then made into a data narrative which is then drawn to a conclusion. This conclusion is expected to represent the perspectives of the community, institutional organizations, tourists, and all stakeholders involved in the region.

\section{RESULT AND DISCUSSION}

The development of marine tourism in the Mandeh area is one of the development alternatives offered in this study. The development of marine tourism expect the participation and empowerment of the local community, so that people do not feel like a guest at home. However, the community can be a part of any tourism development carried out by the local government, either in planning or implementing tourism development.

The community approach is one approach to tourism development that emphasizes maximum community involvement in the process of developing marine tourism. There are some basic principles that must be understood, namely:

1. The principle of co-ownership is that the marine tourism area is shared property, the community rights in it must be recognized, but the protection must be done together as well.

2. The principle of co-operation / co management is that joint ownership requires the coastal management which can be carried out together with all community components (stakeholders) consisting of government, community and non-governmental organizations (NGOs).

3. The principle of co-responsibility is that the existence of a marine tourism area is a shared responsibility, because the management of a marine tourism area is a shared goal.

Besides the three principles in the development of marine tourism above, the main key in analyzing the development of marine tourism in the coastal area of Mandeh Pesisir Selatan among others, is marine tourism activities that can be developed in a coastal area adapted to the resources and potentials that are owned by the people of the area. Based on observations and findings in the field, it is known that some of the resources and potential is available in the Mandeh tourism area. It can be seen in the table below: 
Table 1

Existing Resources and Potential in the Mandeh Tourism Area that Can Be Developed by the Community

\begin{tabular}{lllc}
\hline No & $\begin{array}{c}\text { Aspects } \\
\text { Observed }\end{array}$ & \multicolumn{1}{c}{ Description } & \multicolumn{2}{c}{$\begin{array}{c}\text { Available } \\
\text { Yes }\end{array}$} \\
\hline 1 & Beach & $\begin{array}{l}\text { This beach can also be used as a place of } \\
\text { recreation and activities such as } \\
\text { relaxing, playing water, or swimming by } \\
\text { the beach }\end{array}$ & $\checkmark$ \\
\hline 2 & Mangrove & $\begin{array}{l}\text { Mangroves which have various types of } \\
\text { biota objects have more aesthetic value } \\
\text { for visitors to enjoy. }\end{array}$ & $\checkmark$ \\
\hline 3 & Diving & $\begin{array}{l}\text { Diving is done to see the beauty of the } \\
\text { underwater coral reef by diving into the } \\
\text { water column to a certain depth }\end{array}$ & $\checkmark$ \\
\hline 4 & Snorkeling & $\begin{array}{l}\text { Snorkeling is also done to see the } \\
\text { beauty of underwater coral reefs, but by } \\
\text { staying on the surface of the water. }\end{array}$ & $\checkmark$ \\
\hline 5 & Fishing line & $\begin{array}{l}\text { Fishing is an activity that utilizes } \\
\text { fisheries resources for fun or sports. }\end{array}$ \\
\hline 6 & Surving & $\begin{array}{l}\text { Surfing is an activity that utilizes waters } \\
\text { by using surfboards. }\end{array}$ & $\checkmark$ \\
\hline
\end{tabular}

Source: Primary Data Processing (2019)

Based on the identification of data about the resources and potential available in the Mandeh tourism area that can be developed by the community in table 1 above, it can be said that the Mandeh area has potential resources that can be developed by empowering the community as implementing actors in the development of marine tourism.

For more details, resources and potential for the development of marine tourism available in the Mandeh tourism area by empowering local communities along the coast of the Mandeh tourist area can be described as follows:

Beach. Beach is a resource that can be used as a tourist attraction for visitors with the beach as the main object. This beach can also be used as a place of recreation and activities such as relaxing, playing water, or swimming by the beach (Hidayat. 2011), and enjoying the scenery and natural panorama, such as the sunrise (sunrise) or sunset (sunset) (Sanam and Adikampana. 2014). In general, the beaches in the Mandeh coastal tourism area have relatively low and shallow waters calm and comfortable water currents to be enjoyed by visitors while playing water by the beach. The beach here is the type of beach that is suitable as a place of recreation, because of the beach has white sand and clean. Because the beach is a resource and potential that can attract the interest of visitors or tourists, in this case the community should always maintain the cleanliness of the beach together and routinely carry out beach cleaning activities. Because with a clean beach will make visitors and or tourists feel at home to enjoy the beauty of the beach longer and will make another visit in other days.

Mangrove. Besides the availability of clean and gentle beaches, in the tourist area of Mandeh there are also mangroves. The thicker mangrove forest here is more interesting to enjoy its beauty. The existence of mangroves that are too dense or too loose is not suitable as a mangrove tourism. Mangroves with more diverse types will certainly be more interesting for visitors. Tidal conditions that are not too high are safe for visitors to enjoy mangrove tourism. Mangroves which have various types of biota objects have more aesthetic value for visitors to enjoy.

Diving. Diving tours are conducted to see the beauty of underwater coral reefs by diving into the water column to a certain depth. Sunny waters are needed in diving tourism so that visitors can see more clearly the beauty in the sea. High coral cover 
becomes more attraction for visitors. The type of life form is certainly more interesting than the monotonous expanse of coral. Various types of reef fish have a higher aesthetic value. The flow is not too heavy become certainly safer for visitors. Deeper coral reefs are needed for diving tourism so that visitors can dive in the water column.

Snorkeling. Snorkeling tours are also conducted to see the beauty of underwater coral reefs, but by staying on the surface of the waters. The suitability of snorkeling tours considers seven parameters with four rating classifications. The suitability parameters of snorkeling tours, namely the brightness of the waters, coral community cover, type of life form, type of reef fish, current speed, depth of coral reefs, and width of flat reefs.

Fishing line. Fishing Tourism is an activity that utilizes fisheries resources for fun or sports. The resource requirements that must be met are convenient locations for fishing and sufficient fish resources. The parameters that need to be considered in fishing tourism are fish abundance, fish species, and water depth. Fishing tourism can be done at sea, on the beach, on a lake or on a boat. Surfing is an activity that utilizes waters by using surfboards. Surfing tours need big waves.

The development of marine tourism needs to be distinguished between physical and non-physical elements. Existing physical elements can be quantified such as accessibility and amenities. The non-physical elements include elements that cannot be calculated in general related to the social culture of the local community, namely the way of life and values, and behavior. The following table is the results of the development analysis:

Table 4.1

Analysis of Maritime Tourism Development Based on Empowerment of Community In the South Coast of the Mandeh Coast

\begin{tabular}{llccccc}
\hline \multicolumn{2}{c}{$\begin{array}{c}\text { Assasment aspect of tourism } \\
\text { attraction }\end{array}$} & \multicolumn{2}{c}{ Available } & \multicolumn{2}{c}{ completeness } & \multicolumn{2}{c}{ Physic condition } \\
\cline { 2 - 7 } & Yes & No & Adequate & No & Good & Bad \\
\hline Concept & Government & $\checkmark$ & $\checkmark$ & & $\checkmark$ & \\
\cline { 2 - 7 } $\begin{array}{l}\text { of Mandeh Beach } \\
\text { marine tourism } \\
\text { development in }\end{array}$ & Stakeholder & $\checkmark$ & $\checkmark$ & & $\checkmark$ \\
\cline { 2 - 7 } Pesisir Selatan & Community & $\checkmark$ & $\checkmark$ & & $\checkmark$ \\
\cline { 2 - 7 } & & $\checkmark$ & & $\checkmark$ & $\checkmark$ \\
Accessibility & & & & \\
Amenity & $\checkmark$ & & $\checkmark$ & $\checkmark$ & $\checkmark$ \\
Attraction & $\checkmark$ & & $\checkmark$ & $\checkmark$ & $\checkmark$ \\
\hline Infrastructure support around & $\checkmark$ & & $\checkmark$ & \\
area & $\checkmark$ & & $\checkmark$ & $\checkmark$ & \\
\hline
\end{tabular}

Source: Observation Results (2018)

Based on the results of identification and data processing carried out when the researcher is in the field, there are several analyzes of the development of marine tourism in the coastal area of Mandeh Pesisir Selatan. The factors namely (1) Government, (2) Tourism Actors, (3) Community, and (4) accessibility, (5) amenities, (6) adjustments, and (7) Contacts. Factors that can be proposed as an abstract form of business value in the framework is (1) increasing competitiveness and added value for regional tourism products; (2) can increase the economic growth of local communities; and
(3) it is expected to be able to improve the region of a marine tourism destination in the coastal province of South Sumatra, West Sumatra.

This factor analysis also found factors that could actually increase the role of community human resources which has effective and efficient operational arrangements in order to encourage the realization of development as a marine tourism area. This is also one part of the strategy launched by the regional government in relation to the development of 
tourist areas based on community empowerment.

The findings in the field shows about the growth of the community in the Mandeh tourism area in the last 10 years, changes in the fisheries sector such as coffee shops, sales of transportation services such as boat engines / speedboad. If the development of marine tourism is possible, not only the top sectors that can be developed by the community, but other sectors that can be used as community livelihoods such as diving, snorkeling, and surfing.

Diving tour can be done by visitors to this region. This is done to see the beauty of the underwater coral reef by diving into the water column to a certain depth, because the Mandeh area has a very large and beautiful coral reef. So, with this condition, local people who have potential diving expertise can provide services to visitors to enjoy the beauty of underwater coral reefs.

The tourism sector is one of the potential possessed by the people in the Mandeh tourism area. For this reason, the community must support every policy made by the government in managing tourist objects in the region. People have started to think that they have the potential that can be developed and utilized to support marine tourism activities here. They have skills in diving, swimming and riding a speed boat / engine boat, all of which can be used as a source of livelihood for them.

The people of Mandeh region have realized that they have the potential of natural and human resources in the form of expertise not possessed by other communities. They have realized that both potentials can be implemented in the management of attractions independently or in collaboration with the government through the tourism development program. The community has realized that having the two potentials they have will give an impact on improving people's economic lives. The economic sector can be developed by the community by increasing their participation in creative and innovative marine culinary preparations. The Mandeh tourism area can be used by the community as a culinary center for foods whose raw materials are from the sea, such as seafood and other traditional food with seafood specialties. So when the tourists visit this tourism, they will look for these special foods besides enjoying the natural beauty of the Mandeh region.

If we pay attention to developments since the opening of the Mandeh area into a mainstay tourist attraction in South Coast and West Sumatra, so far the community has not been involved in matters relating to the planning of developing and managing tourist objects in an integrated manner with the government. The management of attractions is still managed by the government, so it is considered not to provide a positive value or positive impact on the economy of the local community. The community hopes that their potentials can be used as a part of the development of this tourism area. So, they are not only become guests in their own homes. So, in developing this marine tourism area, it must refer to the principle of co-ownership, the marine tourism area is shared property, there are community rights in it that must be recognized, but the protection must be done together.

The marine tourism development model using the community empowerment approach is one of alternatives that can be implemented in the Mandeh tourist area based on the results of field studies that have been carried out. In this model, it will also involve actors, namely government, private sector, and the community. Each of these actors is expected to take a joint action in accordance with their respective roles. This model also emphasizes giving greater roles to the community in the end. Where in the planning stage the development of the community plays less role than the government, at the implementation stage the community has begun to play a role as implementing the development and construction of facilities needed in the development of the tourist area, and at the stage of community supervision it is expected to play a full role in developing various creativities and innovations, maintaining, supervising in order to improve the quality of attractions and at the same time make the potential that already exists as a source of livelihood for the community.

For more details about the portion of community involvement in the development model of marine tourism based on community empowerment can be illustrated in the reverse triangle below: 


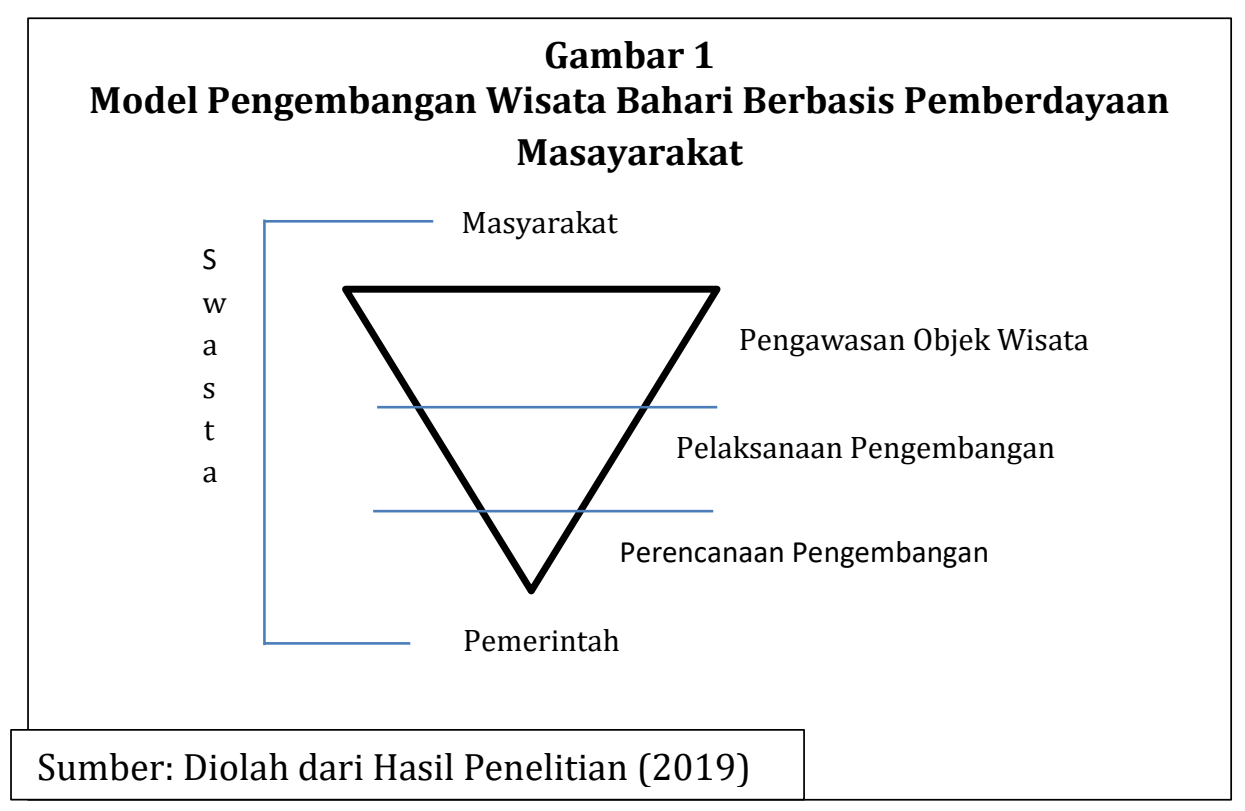

The marine tourism development model based on community empowerment as described in the above, the community can be seen in several stages, including: planning, Implementation stage, and Supervising stage. In some stages it shows a shift in the process of tourism development. At the planning stage, the government plays a full role and becomes very central. Considering that the government has a vision and mission in regional development, so the government's commitment in tourism development has been stated in the regional development mission and there is also a master plan for tourism area development, Regional Tourism Development Master Plan (RIPPDA). In addition, at this planning stage, the role and participation of the community is still not visible.

At this planning stage community involvement still needs direction what they have to do in the development of tourism related to acting and behaving. In addition, the government must also cooperate with the private sector, because the establishment of this collaboration will foster sustainability of the program. In this planning stage the community has begun to feel the benefits of the tourism industry in their homes, it will raise awareness to maintain or strengthen their position through a series of activities in the world of tourism. When people feel the benefits of the existence of the tourism industry, the sense of belonging will emerge. Moreover, the sense of belonging to the tourism industry become part of themselves and their lives.

\section{CONCLUSION}

From the findings and analysis of the marine tourism development based on empowerment of community as a whole it can be concluded into three things, namely:

1. Mandeh tourism area has the potential of marine resources and can be utilized by the community itself in accordance with the potential and expertise they have. Various kinds of socialization and intensive business carried out by stakeholders have not been well integrated and have not been well connected to one another. Even though as a marine tourism destination it has the better potential to develop. Thus in the future benefits will be both financially and welfare of the community.

2. The development of marine tourism can be done by using an empowerment of community based approach by emphasizing full involvement of the community in the process of developing marine tourism, such as selling diving services, swimming, crossing one island to another by providing speedboad transportation services.

3. The development approach with community empowerment can be carried out through several stages, namely: the planning stage, the implementation phase, and the supervision stage. 
This can be increased again in the future through several activities, namely (1) increasing the capacity of human and natural resources; (2) coordination between regional tourism institutions; (3) Planning the concept of marine tourism development by involving cross-sectoral. Related to increasing the capacity of resources can be done through training activities for tourism conscious groups and the community directly.

The training can be in the form of training. Besides giving them income this can also help improve the quality of the destination. In addition, other resources also need to be improved, such as increasing amenities for tourists. The existence of restaurants, improvement of facilities in the form of markers (signage) and also making other information suggestions can also improve the quality of tourist destination areas. In order to improve coordination between tourism institutions in the region, this can be done by carrying out various activities such as through the formation of focus group discussions, supporting the participation of tourism associations such as the Travel Agent Association, the Indonesian Hotel and Restaurant Association, the Tourism Promotion Board and the Indonesian Tourism Association for the development the region. A better coordination between institutions will make a travel package in the future more mutually supportive. In addition, this support could have been encouraged in the form of promotion of a shared area with other destinations in the Mandeh neighborhood of the South Coastal District of West Sumatra Province.

In the future will be important to help the synergy between stakeholders to enhance the role of stakeholders in the South Coast. In addition, the concept of development can be encouraged through intensification and emphasis on the involvement and role of various institutions in the destination environment such as schools or colleges characterized by tourism, private companies in the form of Corporate Social Responsibility (CSR) directly for the community and also through absorption or male workers regional training who have expertise or interest to work in tourism. These things will be a higher quality improvement in the seafaring of marine tourism in the South Coast of West Sumatra province.

\section{REFERENCES}

Andrea Yanes, Seweryn Zielinski, Marlenny Diaz Cano, and S. K. (2019). Community-Based Tourism in Developing Countries. A Framework for Policy Evaluation.

Anuar, A.N.A. \& Sood, N. A. A. (2017). Community Based Tourism: Understanding, Benefits and Challenges. Journal of Tourism and Hospitality, 6(1). DOI:

Chaniago, A. A. (2014). Rencana Pembangunan Jangka Menengah Nasional 2015-2019. Kementerian Perencanaan Pembangunan Nasional/ Badan Perencanaan Pembangunan Nasional.

Hidayat, M. (2011). Strategi Perencanaan dan Pengembangan Objek Wisata (Studi Kasus Pantai Pangandaran Kabupaten Ciamis Jawa Barat. Tourism and Hospitality Essentials (THE) Journal, 1(1).

Kebudayaan, D. P. dan. (2018). Data Potensi, Kebijakan dan daya Tarik Bidang Destinasi Pariwisata Kabupaten Pesisir selatan.

Mearns, K. (2015). Applying Sustainable Tourism Indicators to CommunityBased Ecotourism Ventures in Southern Africa. Athens Journal of Tourism, 2(3).

No.10, U. (2009). About tourism.

Page, S. (2009). Tourism Management: Managing for Change. Burlington, MA: Elsevier Ltd.

Pitana, I.G. \& Gayatri, P. . (2005). Sosiologi Pariwisata. Andi Offset.

Rubin, A. \& Babbie, E. (2008). Research Methods for Social Work. Brooks/Cole.

Sanam SR, A. I. (2014). Pengembangan Potensi Wisata Pantai Lasiana sebagai Pariwisata Berkelanjutan di Kota Kupang, Provinsi Nusa Tenggara Timur. Jurnal Destinasi Pariwisata, 2 (1).

Sastrayuda. (2010). Strategi Pengembangan dan Pengelolaan Resort and Leisure. Hand Out Mata Kuliah Concept Resort and Leisure.

Tosun, C. (2004). Expected nature of community participation in tourism development, School of Tourism and 
Hotel Management. Mustafa Kemal University, 31200 Iskenderun, Hatay, Turkey.

Yahya, A. (2019). Menpar Tinjau Kawasan Wisata Mandeh di Sumbar. Republika.co.id.

Yulius, D. (2018). Kriteria Penetapan Zona Wisata Ekowisata Bahari. Pusat Riset Kelautan Kementerian Kelautan dan Perikanan. IPB Press. 